\title{
Irans unge - mellem modernitet og tradition
}

\section{Karin Bergquist}

De unge følger ikke længere religiøse ledere i deres dagligliv og mange beder ikke tre gange dagligt. De ønsker et opgør med politisk islam og islamisering af politikken, men kan ikke opstille klare alternativer

Farhad Khosrokhavar: Avoir vingt ans au pays des ayatollahs, $405 \mathrm{~s}$. Edition Robert Laffont, Paris 2009.

Irans unge er fanget imellem lysten til modernitet og angsten for det fremmede. Det gælder i det personlige som i det politiske liv.

Teherans ungdom har længe været optaget af vestlige værdier, men ny forskning viser, at store dele af Irans unge ikke længere slutter op om de religiøse værdier, som den islamiske revolution bygger på. Det fremgår af bogen Avoir vingt ans au pays des ayatollah af den iranske religionsprofessor Farhad Khosrokhavar, som bygger på tre års arbejde og 66 interviews med unge iranere $\mathrm{i}$ Qom syd for Teheran. Qom er Irans religiøse hovedstad, hvor hovedpar- ten af præsteseminarerne befinder sig og hvortil den iranske befolkning, særligt fromme familier, valfarter for at afholde religiøse ceremonier og hylde deres foretrukne helgener.

\section{Religion til forhandling}

Irans unge afviser såvel revolutionens religiøse og patriarkalske leveregler som tanken om martyriet, der var kernen i den islamiske revolution. Under Iran-Irak-krigen fra 1980-1988 blev martyriet forbundet med at ofre sig i krigens tjeneste, hvor op imod $1 / 2$ mio. iranere mistede livet eller blev invaliderede, $\mathrm{fx}$ de mange unge drenge, der blev brugt til at rydde miner. Dengang var familier stolte og lykønskede hinan- 


\section{LITTERATUR}

den, når deres sønner var blevet ofre i kamp. I mange år efter krigen var det pensum i skoler og universiteter at læse martyrernes dagbøger, som Ministeriet for Kultur og Islamisk Vejledning havde opfordret soldaterne til at skrive, og gerne $\mathrm{i}$ poetisk stil. I dag kan mange iranske unge slet ikke forestille sig at gå $i$ krig og forsøger alverdens krumspring for at undgå militærtjeneste. De tror slet ikke på et hinsides liv.

Martyriet forbindes i dagens Iran med Basij-folk, der er kendt for deres råhed. Det var dem, der gjorde 'det beskidte arbejde' under IranIrak-krigen og i dag er deres funktioner især civile. De overvåger unge menneskers tøjstil og adfærd. Præstestyret betaler grupper for at chikanere og forfølge politiske modstandere, men også at gribe ind over for uskyldige unge mennesker, hvis adfærd er støjende eller anderledes. Man hører historier om unge mennesker, der pludselig forsvinder, bliver fængslet, udsat for tortur og siden myrdet. Under de voldsomme uroligheder, der efterfulgte præsidentvalget i juni er de igen i funktion. De unge har lært, at kritik bliver mødt med overgreb. Ønsker man noget i livet, fx på universitetet, skiller man sig ikke for meget ud og påkalder sig ikke negativ opmærksomhed. Basij forsvarer teokratiet og princippet om, at magten er koncentreret hos den øverste leder og modtager særlige privilegier for deres indsats. Basij er klar til at under- lægge sig en radikal version af islam og til at dræbe i islams navn. De udgør ikke længere rollemodeller for Irans unge, snarere tværtimod.

Mange unge tager også afstand fra religionens kollektive ceremonier. Religion bruges pragmatisk i en turbulent og uforudsigelig tid. De tager hvad de kan bruge og lader resten ligge. De shopper rundt mellem religioner og er også optaget af overtro og mystik, fx sufisme, en pre-islamistisk trosretning, der i dag er knyttet til modstand mod styret, pga. statens overgreb på de godt 10.000 sufister, der findes tilbage $\mathrm{i}$ Iran. Filosofi vinder også indpas hos de unge, især retninger, der kan kombinere tro med valgmuligheder, fx Kierkegaard.

Religion er hele tiden til forhandling, over for forældrene og mellem kønnene. Førhen var det normen at følge leveregler, udviklet af en storayatollah, i alle livets spørgsmål. Ayatollah Khomeini var en storayatollah, som der kun er 7-8 tilbage af i dagens Iran. Men de unge afviser gradvist sådan en levevis og foretrækker at være aktører i deres eget liv. Det gælder alt fra islamisk tøjstil til adfærd. Det er fx blevet acceptabelt at drikke alkohol. Førhen var det forbundet med stor skyld og man forsøgte at kompensere med almisser og fromme handlinger, mens det i dag er langt mere hyppigt, især jo tættere man kommer på Teheran. Pigerne presser mest på for forandringer i Iran, da det er dem, der er 
mest undertrykt i den islamiske kultur. Manden må gifte sig med fire kvinder. Der skal to kvindelige vidner i en retssag mod ét mandligt vidne. Kvinden arver halvt så meget. Piger bliver myndige og kan straffes i en alder af ni, modsat 13 år for drenge, selvom 18 år for begge køn er ved at blive vedtaget. Listen over uretfærdigheder over for kvinder er lang inden for islam. Derfor ser man flere piger tage livet i egen hånd. Nogle bruger fortsat meget tid på religiøse handlinger og at bede om gode karakterer forud for en eksamen, særligt i Qom, mens andre er mere indstillet på at yde et konkret arbejde for at opnå succes.

\section{Ambivalens, tvivl og frygt}

Samtidig er der hos iranske unge en stor ambivalens i forhold til religionen, fordi der er så meget skyld forbundet med at afvise den traditionelle levevis, som også forældrene står for. Hele tiden svinger de mellem at afvise religionens snærende bånd og lysten til frigørelse. Ofte sker udviklingen diskret og gradvis. Sekulære normer vinder frem i takt med oprør mod forældrene, særligt i Qom, mens situationen i Teheran er anderledes. Her har borgerskabets elite længe været tiltrukket af sekulære ideer.

De unge har dog ikke så mange bud på alternativer. De har ikke levet under de mere frie vinde under shahen som deres forældre. Det er svært helt at forkaste religiøse traditioner og præstestyret, når man ikke ved, hvad man skal sætte i stedet.

Manglende erfaring med andre politiske systemer handlingslammer unge iranere og er hovedårsagen til præstestyrets fortsatte beståen. De unge ønsker at følge globale kulturelle normer frem for religiøse. Men angsten for det ukendte - for opløsning af skikke og normer - lurer. Frihed skaber angst og frygt for kaos. Hvad sker der, hvis man giver los?

Hos nogle fører det til en udbredt social skizofreni at leve i en moderne og en traditionel tidsalder, mens andre sagtens kan pendle ind og ud mellem kulturelle og religiøse normer. Fx har mange adgang til satellitter, og det er almindeligt at se alle slags film i hjemmet om moderne forhold mellem kønnene, men udenfor på gaden ser man dårligt på hinanden, særligt i Qom. Kontrasten mellem den indre og den ydre verden er massiv, og karaktertyper som den dobbelte personlighed er udbredt.

\section{Betydningen af køn og geografi}

Den sociale kontrol med piger er stor, især i Qom. Pres vedr. brug af tørklædet er massivt, fordi en pige uden tørklæde opfattes som en pige uden religion. Og pigen opfatter tørklædet som kernen i den islamiske identitet. Mange piger i byerne forbinder omvendt tørklædetvangen 


\section{LITTERATUR}

med mangel på frihed. Mens piger i Qom følger den islamiske dresscode og går med chador, der dækker hele kroppen fra top til tå, er det mere almindeligt i Teheran at bruge tørklæde - som sagtens kan være farvet og mønstret og blot en stribe over håret - og frakke til knæet, men man ser den også kort og kropsnær, hvor pigen åbenlyst flasher sin bagdel. Mens nogle piger, især i Teheran, bruger make-up for at gøre sig smukke, så dækker andre sig til for ikke at tiltrække sig opmærksomhed i Qom. Fordelen ved en chador er i øvrigt, at man kan holde i hånd uden at nogen ser det.

Mens man nøjes med at kaste stjålne blikke i Qom, er det blevet mere almindeligt at holde $\mathrm{i}$ hånd $\mathrm{i}$ Teheran. Mens kæresteforhold er platoniske og bygger på idealisering af den anden i Qom, er før-ægteskabeligt samkvem og skiftende partnere mere almindeligt i Teheran. Pigen forventes stadig at have sin $\mathrm{m} \varnothing-$ dom intakt, særligt i Qom, hvor hun ellers bliver stigmatiseret, og manden har ret til at forlade hende.

Uligheden mellem kønnene starter i skolen. Mens det er almindeligt for unge iranske mænd frit at vælge ægtefælle, kolliderer ønsket om selv at vælge ægtemand for pigens vedkommende ofte med behovet for familiens beskyttelse. Drenge er inkonsekvente i deres opfattelse af frigørelse og seksualitet. De vil selv have mulighed for frit at dyrke sex, men tolererer ikke, at nogen har sex med deres søster. De er tiltrukket af piger med make-up men vil ikke have, at deres egen kæreste eller søster skal bruge make-up. Det er pigens egen skyld, hvis hun bliver voldtaget, så kan hun bare lade være med at gå ud. Den slags antagelser hænger sammen med, at kvinden mange steder stadig opfattes som mandens ære.

Mange iranske piger ønsker i $\varnothing v$ rigt ikke fuld lighed. Nye adfærdsmønstre mellem kønnene vinder frem. Det bliver fx mere almindelig at have elskere, især iblandt eliten, men også i middelklassen. Det øgede fokus på kvindens seksualitet giver skyldfølelse, især hos unge kvinder. Pigerne kan frigøre sig på to måder. Enten via afvisning af traditionen eller revolte, fx ved at flytte til Teheran. Eller hun tilpasser sig, samtidig med at hun bruger de friheder, som moderniteten tilbyder. Kompromiset er udbredt.

Iranske piger er ofte misundelige på drengene, fordi de er mere frie. Af samme grund udvikler iranske piger stadig mere vilde fritidsbeskæftigelser, fx kampsport, og piger udgiver sig for at være drenge, til drengenes store fortrydelse. Mens drenge i Qom stadig sænker blikket for ikke at møde pigens blik, så er han tvunget til at kigge direkte på alle $\mathrm{i}$ Teheran for at afgøre kønnet. I fattige kvarterer er vilkårene for piger værst. De får ikke lov at gå i skole, hvis læreren er en mand, og bliver i stedet tidligt gift. $10 \mathrm{ud}$ af 100 kvin- 
der får lov at arbejde i Qom. I alt udgør kvinderne ca. $15 \%$ af arbejdsstyrken i Iran, men fylder ca. $2 / 3$ i arbejdsløsheds-statistikkerne.

\section{Islamisering af uddannelse}

Den omfattende islamisering af uddannelsessystemet i revolutionens start har ikke gjort iranske unge mere religiøse, snarere tværtimod. Takket være den islamiske republiks politik med gratis uddannelse og nationale læsekampagner kommer iranske studerende i dag fra brede lag i befolkningen, både socialt, etnisk og geografisk. Alle har desuden adgang til internet på universiteterne.

Islamiseringen af uddannelsessystemet i den islamiske republik betød samtidig en forringelse af undervisningen, hvor bøger blev udskiftet og islamisk propaganda kom i centrum. Der skete tilmed en skævvridning af undervisningen på universiteterne pga. kvotasystemer, der privilegerede børn af forældre, der tilhørte islamiske grupper.

De unge skal først kæmpe med at komme igennem de meget hårde adgangsprøver for at komme ind på universitetet, siden bliver de underlagt islamiske læreres undervisning, og politiske aktiviteter bliver overvåget af islamiske studentergrupper. Bagefter venter en markant ungdomsarbejdsløshed.

Men unge iranere forventes at tage en uddannelse, og de unges fo- restillinger om at være aktører i eget liv hænger da også i høj grad sammen med at kvalificere sig til et godt job sidenhen.

Iranske universiteter domineres i dag af 65 pct. kvinder, selvom mange piger går på universitetet for at finde en mand og bruger ikke deres uddannelse siden hen. Kvinderne presser også mest på for ændringer, fordi de alle er udsat for uretfærdig behandling, i hjemmet, på arbejdspladsen, i det offentlige rum, i lovgivningen osv.

Men man skal ikke tage fejl. Iranske feminister er ikke nødvendigvis de samme som støtter sekularisering. Bevægelsen er splittet og går fra det yderste venstre til det yderste højre. Man kan sagtens være feminist og religiøst konservativ samtidig. Der er flere kvinder i det iranske parlament, og to kvindelige ministre i Ahmadinejads ny regering, men ikke-troende parlamentsmedlemmer tillades ikke. Fælles for den iranske kvindebevægelse er dog ønsket om reformer, snarere end om en ny revolution. Det samme gælder de unge, der erstatter politisk aktivitet med vestlige værdier og materialisme.

De unge siger, at de føler sig lukket inde i en ældgammel kultur, der ikke byder på tiltrækkende fremtidsmuligheder. Derfor ønsker især veluddannede at rejse til udlandet, enten for at videreuddanne sig eller få job et par år, mens flere bliver væk. Ifølge den internationale valu- 


\section{LITTERATUR}

tafond forlader mere end 200.000 universitetsuddannede hvert år Iran, og 25.000 studerende læser på universiteter uden for Iran. Uofficielle tal menes at være dobbelt så høje.

\section{Individualitet før politik og religion}

De unge er i fuld gang med at udvikle mere individuelle omgangsformer, bl.a. via brug af moderne kommunikationsmidler som mobiltelefon og internet. Den traditionelle sørgekultur, der muliggjorde kollektive følelsesudbrud, er udskiftet med en fritidskultur, der peger i retning af individualisering via nye fritidsaktiviteter. Sport og fitness er blevet moderne. Alle hører musik, og især rapmusik er populært.

Musik opfattes dog som farligt, fordi man kan miste kontrollen, og unge risikerer at få konfiskeret båndoptagere i biler og busser. Litteratur giver luft og håb om andre livsformer. Internet giver adgang til moderniteten, nye horisonter, venskaber og nye sociale normer. Selv præsterne surfer på nettet.

Også på det politiske plan er en stor inkonsistens i de unges tankeverden. De er på en gang moderne og traditionelle. De har en stor lyst til at deltage i moderniteten, men har ingen klar idé om, hvilket andet politisk system, de kan sætte i stedet for præstestyret, for de har ikke andre politiske erfaringer. Det skal ikke være et fuldstændigt verdsligt system, mener mange, der føler be- hov for et religiøst fællesskab trods alt. Det skaber enhed, hvorimod demokrati nemt kan skabe kaos.

Derfor retfærdiggør mange unge fortsat det meget ambivalente religiøstpolitiske system, som den islamiske revolution bygger på. I praksis er stadig flere, især jo mere man nærmer sig Teheran, politisk og socialt progressive samtidig med at de er religiøst konservative. Om det er islam eller en folkevalgt demokratisk forsamling, der skal afgøre væsentlige modstridende værdier, kan være svært at afgøre. Mens unge i Qom ønsker et religiøst demokrati, foretrækker Teherans unge dog adskillelse mellem religion og politik.

Generelt tror de unge ikke meget på politik og oplever en mur mellem staten og politikerne på den ene side og befolkningen på den anden. De unges massive boykot af valget i 2005 menes at have banet vejen for præsident Afmadinejad.

De tager dog i stigende grad afstand fra præsteskabet som Irans legitime politiske ledere, fordi præsterne i tre årtier har beriget sig på befolkningens bekostning og ikke har forvaltet den politiske magt hensigtsmæssigt. Præsternes manglende forståelse for landets økonomiske problemer og befolkningens sociale behov er en hån over for den udbredte fattigdom. Præsterne burde ikke være ved magten, men ved siden af magten, siger de.

De unge ønsker dog ingen ny revolution. Dertil har de hørt for me- 
get tragisk fra forældrene, der mistede deres ungdom i overfyldte fængsler. De oplever heller ikke, at revolutionen har været til deres fordel. Tværtimod har den ruineret og ødelagt landet. De unge er presset på alle måder. Mange har ikke noget arbejde, da ungdomsarbejdsløsheden er på 30-40 pct. De har ringe adgang til understøttelse og social sikring. Muligheden for at få lån er begrænset, og tårnhøje renter skal betales tilbage. De har ikke råd til at gifte sig, men ægteskabet opfattes som et betydningsfuldt skridt ind i voksenlivet.

De svære vilkår presser mange unge ud i kriminalitet og narko, andre falder ned i depression og bliver handlingslammede. Frygten for styrets overgreb har medført megen politisk apati.

\section{Efterskrift}

Urolighederne efter præsidentvalget i sommeren 2009 var et wake-up call for de unge, som ellers havde mistet troen på politik. De fik håbet om, at de kunne vælge en ny præsident, så blev valget stjålet fra dem, og håbet bristede. Så kom vreden over at se basij-militsen slå ned over for venner i gaderne og høre, at unge blev voldtaget i fængslerne og henrettet for at demonstrere.

Den vrede er ikke nem at tæmme og kan resultere i øget radikalisering. De unge vil noget helt andet end deres forældres generation og peger ikke længere på Mousavi og Karoubi som deres ledere. Demonstrationsbevægelsen er især ung, og den bliver større og større, men i øjeblikket er den leder-løs. Det kommer til at tage noget tid for den at skabe sit eget fundament og udpege egne ledere.

Karin Bergquist er journalist og forfatter til bogen: 'Revolutionens børn. Unge i Teheran', der udkom i 2009 på forlaget Tiderne Skifter. 